\title{
ANALISA STRATEGI PEMASARAN INTERNASIONAL PT. MUSTIKA RATU TBK DI SAUDI ARABIA
}

\author{
Oleh : Sapto Hadi Imambachri BSc., MM. \\ simambachri@yahoo.com
}

\begin{abstract}
ABSTRAK
Penelitian yang berjudul Analisa Strategi Pemasaran Internasional PT. Mustika Ratu Tbk, bertujuan untuk menganalisa strategi pemasaran Internasional di Saudi Arabia, dalam penelitian ini ada empat variabel yang menjadi perhatian, yaitu: Market screening technique yang digunakan sejauh mana Global entry strategy berpengaruh terhadap pemasaran Internasional, faktor-faktor yang mempengaruhi pemasaran internasional PT. Mustika Ratu, dan perilaku konsumen.

Penelitian deskriptif kualitatif ini dilaksanakan dengan menggunakan kuesioner terhadap 30 responden dan dapat disimpulkan bahwa strategi pemasaran internasional PT. Mustika Ratu belum dilaksanakan dengan baik karena dari hasil penelitian hanya sekitar $60 \%$ - $80 \%$ dari strategi pemasaran internasional yang seharusnya dilakukan. Analisa SWOT dilakukan dengan pembobotan yang didapat dari kuesioner yang disebarkan, kemudian diambil proporsinya, sedangkan score didapat dari rata-rata kumulatif setiap pertanyaan kemudian diterjemahkan dengan menggunakan diagram kartesius, maka dapat terlihat elemen strength: tidak terlalu kuat tetapi pada elemen opportunity: masih terbuka lebar, sehingga strategi progresif adalah strategi yang tepat untuk dilaksanakan dalam pengembangan penjualan di Saudi Arabia.
\end{abstract}

\section{Kata Kunci : Analisa Strategi Pemasaran, Analisa SWOT}

\section{PENDAHULUAN}

\section{A. Latar Belakang Masalah}

PT. Mustika Ratu terbuka (tbk) adalah sebuah perusahaan dengan skala nasional yang didirikan pada tahun 1975 dengan memulai industrinya dalam skala kecil. Usaha Jamu dimulai dari garasi pendirinya yaitu Ibu BRA Mooryati Soedibyo dengan hanya membuat beberapa macam jamu untuk memenuhi kebutuhan kerabatnya. Seiring dengan waktu serta mengingat bahwa jamu adalah sebuah peningggalan ilmu pengetahuan dari nenek moyang bangsa Indonesia yang perlu di lestarikan dan sangat digemari oleh kebanyakan masyarakat 
Indonesia pada umumnya, maka PT. Mustika Ratu mulai mengembangkan usahanya kearah industry untuk dapat memenuhi permintaan pelanggannya.

PT. Mustika Ratu mulai mengembangkan pasar ekspornya di tahun 1990 ke beberapa negara tetangga seperti Malaysia dan Brunei Darussalam, pemasaran internasional menjadi keharusan dengan adanya Asean Free Trade Agreement yang diberlakukan tahun 2003, dan tahun 2010 adalah China Asean Free Trade dimana batasan batasan untuk melakukan pemasaran di negara tetangga makin diperkecil, mau tidak mau persaingan menjadi sesuatu yang tak terelakan di berbagai belahan dunia pada masa mendatang. Sampai dengan saat ini PT. Mustika Ratu telah mengekspor produknya ke lebih dari 25 negara di dunia dengan berbagai strategi penetrasi pasar International. Persaingan di dunia International tentulah sangat ketat dimana kualitas produk, harga, distribusi, promosi memainkan peran yang sangat besar dalam menentukan keputusan konsumen untuk melakukan pembelian produk.

Ekspor ke Saudi Arabia dimulai oleh seorang pimpinan perusahaan di Saudi Arabia yang sedang berkunjung ke Jakarta melihat produk yang menarik dan melihat adanya peluang bisnis kemudian bertekad untuk menjalin kerja sama, yang kemudian ditanggapi oleh PT. Mustika Ratu Tbk, dengan cepat, dan mulai memasarkan produk jamu dan kosmetik berjumlah tiga ratus produk dan kemudian setelah tiga tahun,jumlah produk berkurang menjadi empat produk yaitu Jamu tea, Jamu tea honey, Tonic tea, Ginteh dan penjualan terlihat stagnan.

Disamping itu peran dari seorang ekspor manager atau International Sales Manager sangat menentukan akan keberhasilan pemasaran International, sehingga tuntutan akan wawasan/pengalaman international, pendidikan, kemampuan berbahasa Inggris sebagai bahasa pengantar International ditambah dengan bahasa asing yang lain sangat diperlukan oleh seorang Manager Ekspor dalam pergaulan International seperti disebutkan oleh Liane Voerman dalam tesisnya yang berjudul The Export Performance of European SMEs dalam rangka pengembangan bisnis perusahaan. Seperti kutipan dibawah ini:

Some evidence exists that higher educated managers perform better on the international market. For example, Nakos, Brouthers \& Brouthers (1998) find a direct positive effect on both export ratio and export profitability. 


\section{B. Identifikasi Masalah}

Berdasarkan uraian latar belakang diatas, maka diidentifikasikan permasalahan permasalahan yang ada pada PT. Mustika Ratu terkait pemasaran di Saudi Arabia :

1. Pemilihan distributor PT. Mustika Ratu di luar negeri tidak melalui screening.

2. Faktor - faktor yang berkaitan dengan legal, network, finance merupakan masalah tersendiri dalam pemasaran Internasional.

3. kesulitan dalam pelaksanaan strategi pemasaran Internasional khususnya masalah Kualitas produk dan promosi

4. Produk yang dipasarkan oleh distributor sangat terbatas.

5. Peraturan impor yang berbelit.

6. Produk Jamu dan Kosmetik dari Indonesia belum dikenal luas.

\section{Pembatasan Masalah}

Berdasarkan identifikasi masalah diatas, maka penulis membatasi penelitian ini hanya pada faktor faktor yang sangat penting saja :

1. Pemilihan distributor PT. Mustika ratu di luar negeri tidak melalui screening.

2. Faktor-faktor yang berkaitan dengan legal, network, finance merupakan masalah tersendiri dalam pemasaran Internasional.

3. kesulitan dalam pelaksanaan strategi pemasaran Internasional khususnya masalah Kualitas produk dan promosi

\section{Perumusan Masalah}

Mengingat keterbatasan penulis yang berkaitan dengan masalah pustaka, pengetahuan, jarak dan biaya, maka penulis hanya membatasi masalah pada:

1. Bagaimana screening yang berkaitan terhadap pemilihan distributor PT. Mustika Ratu di luar negeri.

2. Bagaimana hambatan - hambatan didalam pemasaran di Saudi Arabia, khususnya yang berkaitan dengan aspek legal, network, dan finance.

3. Bagaimana kesulitan dalam pelaksanaan strategi pemasaran Internasional khususnya masalah Kualitas produk dan promosi . 


\section{E. Tujuan Penelitian}

Penelitian ini ditujukan untuk mendapatkan gambaran mengenai hal-hal yang diperlukan untuk memasuki pasar Internasional di Saudi Arabia

1. Untuk mengetahui screening technique yang digunakan dalam pemilihan distributor di luar negeri.

2. Untuk mengetahui sejauh mana hambatan - hambatan didalam pemasaran di Saudi Arabia, khususnya yang berkaitan dengan aspek legal, network, dan finance berpengaruh terhadap pemasaran Internasional PT. Mustika Ratu di Saudi Arabia.

3. Untuk mengetahui kesulitan dalam pelaksanaan strategi pemasaran Internasional khususnya masalah Kualitas produk dan promosi .

\section{F. Manfaat Penelitian}

Manfaat penelitian ini adalah untuk memberikan gambaran :

1. Bagi perusahaan diharapkan dapat menjadi masukan untuk keperluan pengembangan usaha selanjutnya.

2. Bagi peneliti sendiri sebagai penambahan wawasan untuk lebih mendalami mengenai pemasaran internasional.

3. Bagi civitas akademika Universitas Pamulang penelitian ini dapat menjadi permulaan untuk penelitian selanjutnya di bidang Pemasaran Internasional.

\section{TINJAUAN PUSTAKA}

\section{a. Deskripsi Teori}

Pengertian Pemasaran Internasional:

International business is the activity of engaging in business operations across national boundaries/borders.

International business is the field of study that concerns itself with the development, strategy and management of multinational enterprises in the global context of complex and dynamic business environments. ${ }^{1}$

International marketing is more than exporting because it could involve marketing products that have been manufactured or assembled in the target country, establishing a permanent presence in the foreign country to warehouse and distribute products; licensing

\footnotetext{
${ }^{1}$ Viviek kumar, Amity business school, 2010.
} 
and franchising of the firm 's products to local businesses; sourcing components from foreign states. $^{2}$

Menurut Cateora dan Ghauri (1999) "International Marketing is the performance of business activities that direct the flow of a company's goods and services to consumers or users in more than one nation for a profit. "13

Menurut ketiga teori diatas maka penulis dapat menyimpulkan bahwa pemasaran Internasional adalah suatu aktifitas bisnis yang dilakukan diluar batas negara melalui ekspor, pendirian perusahaan di negara asing, lisensi dan franchise.

\section{b. Landasan Teori}

\section{Hambatan Perdagangan (Trade Barrier)}

Trade barrier adalah salah salah satu faktor penghambat didalam pelaksanaan perdagangan internasional.

\section{Penetapan Harga pada perdagangan Internasional}

\subsection{F O B (Free On Board)}

Barang diterima sampai diatas kapal, pembeli tidak akan dikenakan biaya tambahan sampai barang diatas kapal.

\section{2. $C N F$ (Cost and Freight)}

Harga barang sudah termasuk biaya pengiriman sampai di negara tujuan.

\section{3. $\quad \mathrm{CIF}$ ( Cost Insurance and Freight)}

Harga barang sudah termasuk biaya pengiriman dan biaya asuransi.

\subsection{Strategi Harga Internasional}

Menurut Roger Bannett dalam bukunya International Marketing ${ }^{4}$,

\subsubsection{Cost Plus Pricing}

Metode yang digunakan dengan tidak memperhatikan persepsi dari konsumen dan hanya berdasarkan biaya produksi dinegara asal, tanpa mempertimbangkan harga jual dinegara asing.

\subsection{2. $\quad$ Strategic Pricing}

\footnotetext{
${ }^{2}$ Bennet, R.,Blythe,J.,International marketing,third ed.(Glasgow:Bell \& Bain Itd,2002),p.6

${ }^{3}$ http://www.marketingteacher.com/lesson-store/lesson-international-marketing.html

${ }^{4}$ Bennet,R., International Marketing(Bell \& Bain Ltd,Glasgow,2002) p.289
} 
Banyak perusahaan memulai pemasaran Internasional mereka dengan menjual produk dengan harga yang mengikuti harga kompetitor.

- Skimming

Produk dijual dengan harga tinggi pada saat memasuki pasar dan kemudian diturunkan secara perlahan.

- Penetration

Perusahaan menjual produk dengan harga murah dan dikombinasikan dengan iklan yang agresif dengan maksud untuk mendapatkan market share yang besar.

\section{Metode Pengiriman barang Ekspor}

a. Transportasi

Metode transpor yang digunakan dalam perdagangan internasional dapat berupa :

- Laut

- Udara

b. Dokumen Ekspor

1) Melalui laut

- Bill of Lading dimana Bill of Lading merepresentasikan kepemilikan akan barang

2) Melalui Udara

- Air way Bill (AWB)

Documen ini dikeluarkan oleh perusahaan penerbangan sebagai bukti kepemilikan barang

\section{Kerangka konseptual}

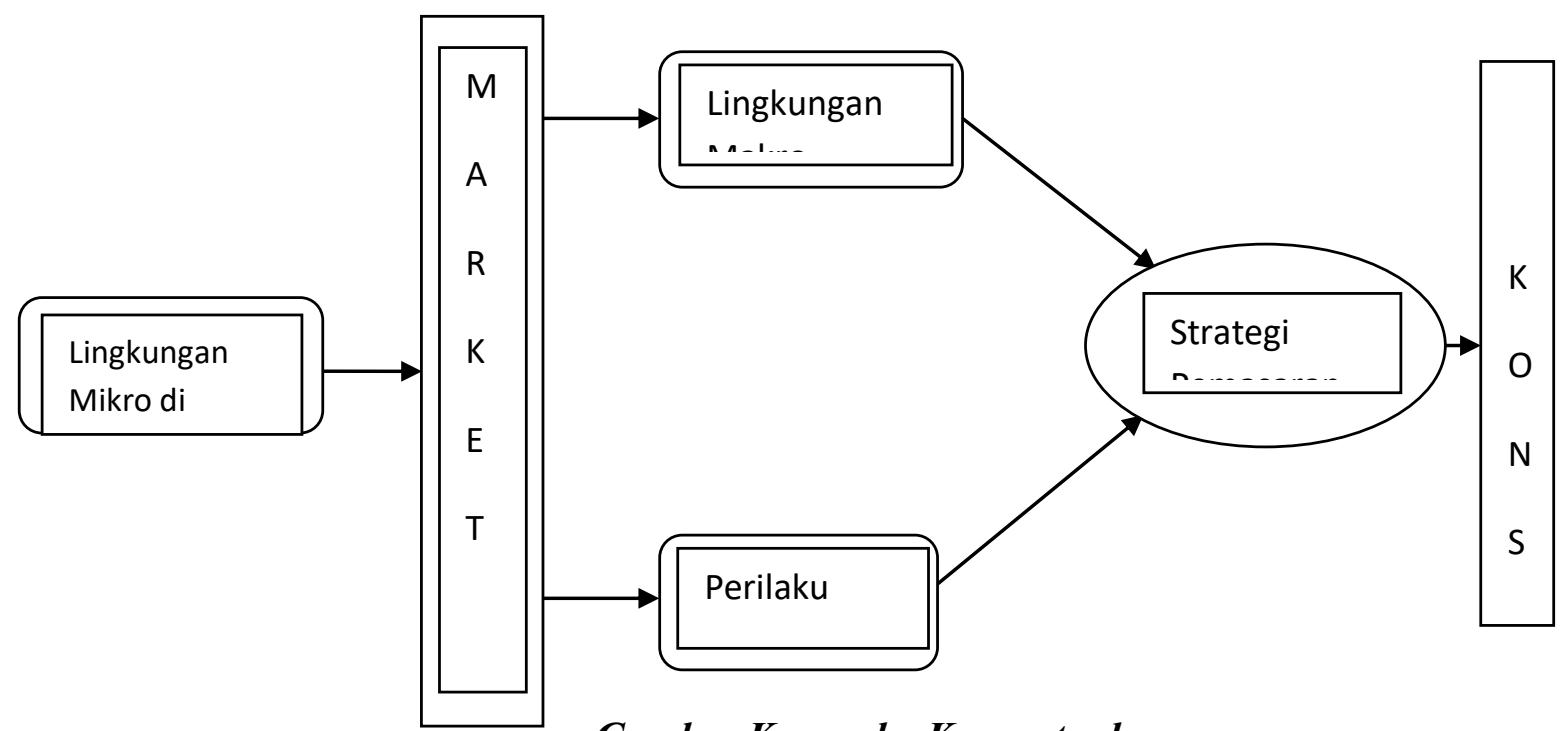

Gambar Kerangka Konseptual 
Pemasaran Internasional dimulai dengan memperkuat lingkungan mikro yang terdiri dari lingkungan internal dan eksternal perusahaan tersebut di Indonesia, kemudian diikuti dengan market screening yang meliputi market size, struktur populasi, income per kapita, politik diikuti dengan perilaku konsumen, akan menghasilkan strategi pemasaran yang berorientasi kepada konsumen.

\section{METODOLOGI PENELITIAN}

\section{A. Tempat dan waktu penelitian}

\section{Tempat penelitian}

Penelitian ini dilakukan di PT. Mustika ratu tbk. Jl. Raya Jakarta Bogor km.26 Ciracas, Jakarta Timur.

\section{Produk Mustika Ratu}

- Mustika Ratu

Merk Mustika Ratu adalah range produk yang lengkap dan diperuntukaan bagi wanita dewasa, wanita usia menoupase serta jamu, produk ini dikelompokan kedalam social economic status (SES) $C$.

- Puteri

Merk Puteri adalah kosmetik remaja.

- Biocell / Biocolor

Biocell/ biocolor diproduksi untuk memenuhi kebutuhan akan kosmetik bagi wanita dewasa dengan social economic status (A).

- Bask

Bask diproduksi untuk memenuhi kosmetik bagi segmen pasar pria dewasa dengan SES(B).

- Taman sari Royal heritage Spa

Produk spa diproduksi untuk memenuhi permintaan pasar akan produk natural, dengan SES A

- Kenanga

Merk kenanga diproduksi untuk memenuhi segmen pasar bawah.

2. Waktu Penelitian

Waktu penelitian dilakukan : selama 4 (empat) bulan, dimulai pada bulan April 2016Juli 2016 


\section{B. Metodologi Penelitian}

Metode yang digunakan dalam penelitian ini adalah metode statistik deskriptif, yang digunakan untuk menerangkan fenomena satu variabel dengan menggunakan analisis deskriptif kualitatif, disini penulis berusaha menggambarkan apa yang menjadi permasalahan dalam penelitian ini dan kemudian menganalisanya berdasarkan kerangka teori yang dipelajari.

\section{Populasi dan Sampel}

Populasi pada penelitian ini adalah karyawan PT. Mustika ratu tbk. dari tingkatan top manager, middle manager dan first line manager, serta karyawan dari semua divisi yang berkaitan dengan pemasaran Internasional dan berjumlah 100 orang

Sample berjumlah 30 orang diambil berdasarkan teknik Non probability Judgment sampling, mengingat bahwa pengetahuan di bidang pemasaran Internasional merupakan keakhlian khusus, yang memerlukan pengetahuan administrative dan pengetahuan lapangan yang didapat dalam kunjungan kunjungan keberbagai negara asing.

Untuk memudahkan analisa data maka dibuatkan data responden seperti di bawah ini :

Tabel III-3. Data Responden

\begin{tabular}{|l|l|c|c|c|}
\hline No & Posisi & Jml. Pria & Jml. Wanita & Total \\
\hline 1 & General Manager & 1 & 1 & 2 \\
2 & Manager & 10 & 6 & 16 \\
3 & Karyawan & 4 & 8 & 12 \\
\hline & \multicolumn{2}{|r|}{} & 15 & 30 \\
\hline
\end{tabular}

\section{Teknik Pengumpulan data}

Teknik pengumpulan data dalam penelitian ini menggunakan beberapa pendekatan:

1. Data primer

Data primer dikumpulkan melalui Interview langsung dengan General Manager ekspor, Manager ekspor wilayah timur tengah, Distribution and Administration Manager divisi ekspor, dan divisi lain yang terkait dengan pemasaran Internasional, serta melalui email dengan distributor PT. Mustika Ratu tbk di Arab Saudi Al-Zohaifi Co.

2. Data Sekunder 
Data sekunder dikumpulkan melalui literatur, internet, buku pelajaran mengenai pemasaran Internasional, Laporan tahunan, Rencana Tahunan.

\section{E. Teknik Analisis Data}

Setelah data dikumpulkan, sebelum disajikan dalam bentuk laporan data diolah dan dianalisis terlebih dahulu. Langkah-langkah yang ditempuh dalam mengolah data sebagai berikut :

\section{F. Hasil Analisis}

Hasil analisis merupakan hasil pengolahan data yang telah dikumpulkan yang kemudian diolah untuk dilaporkan dalam bentuk tabel ataupun bentuk lainnya.

\section{HASIL PENELITIAN DAN PEMBAHASAN}

\section{A. Deskripsi Data}

Dalam melakukan analisa pemasaran Internasional, variabel pertama lingkungan mikro merupakan indikator awal yang menunjukan kesiapan sebuah perusahaan untuk bersaing di pasar Internasional. Pada variabel lingkungan mikro, menurut kotler (Principle of marketing, $2^{\text {nd }}$ edition, $p .84$ ) terdiri dari faktor organisasi yaitu: supplier, perantara, para pelanggan, pesaing dan para anggota masyarakat yang tertarik akan produk itu sendiri. Kemudian setelah varibel pertama dipersiapkan, dilanjutkan analisa market screening technique yang dapat dilakukan, menurut Roger Bennet (International Matketing,third edition, p.185) terdiri dari Market size, Structure of the population, Economic development, Income and wealth, Business environment, Storage and transport facilities, political considerations, local competition.

Langkah selanjutnya analisa lingkungan makro yang menurut kotler ${ }^{5}$ terdiri dari Demografi, teknologi, Budaya, sumber daya alam dilanjutkan dengan analisa perilaku konsumen yang dipengaruhi oleh faktor budaya, social, pribadi dan psikologis.

Dengan memperhatikan varibel variabel diatas, maka selanjutnya dengan menggunakan analisa Internal faktor evaluation (IFE) dan eksternal (Opportunity - Threat) faktor evaluation (EFE) dan digunakannya bobot dari hasil kuesioner yang disebarkan.

\footnotetext{
${ }^{5}$ Kotler, P., Principle of marketing, $2^{\text {nd }}$ edition,p. 89)
} 
Kemudian dimasukan dalam perhitungan Internal-eksternal (Strength-Weakness) matriks (IE matriks) akan dapat diketahui posisi bersaing PT. Mustika Ratu tbk di Saudi Arabia yang pada akhirnya merupakan faktor faktor yang mempengaruhi strategi pemasaran Internasional PT. Mustika ratu tbk di Saudi Arabia.

\section{DATA RESPONDEN}

1. Jenis Kelamin

Tabel IV-1. Tabel Jenis Kelamin Responden

\begin{tabular}{|c|c|c|}
\hline $\begin{array}{c}\text { Jenis kelamin } \\
\text { Responden }\end{array}$ & F & \% \\
\hline Pria & 15 & 50 \\
\hline Wanita & 15 & 50 \\
\hline Jumlah & 30 & 100 \\
\hline
\end{tabular}

2. Usia

Tabel IV-2. Tabel Usia Responden

\begin{tabular}{|c|c|c|}
\hline Usia Responden & F & \% \\
\hline Dibawah 18 th & & \\
$19-35$ th & $\mathbf{1 0}$ & $\mathbf{3 3}$ \\
$36-50$ th & $\mathbf{1 6}$ & $\mathbf{5 3}$ \\
50 th keatas & $\mathbf{4}$ & $\mathbf{1 4}$ \\
\hline & $\mathbf{3 0}$ & $\mathbf{1 0 0}$ \\
\hline
\end{tabular}

\section{Pendidikan}

Tabel IV-3. Tabel Pendidikan Responden

\begin{tabular}{|c|c|c|}
\hline $\begin{array}{c}\text { Pendidikan } \\
\text { Responden }\end{array}$ & F & \% \\
\hline SD & $\mathbf{0}$ & $\mathbf{0}$ \\
SLP & $\mathbf{0}$ & $\mathbf{0}$ \\
SLA/DIII & $\mathbf{1 0}$ & $\mathbf{3 3}$ \\
Universitas & $\mathbf{2 0}$ & $\mathbf{6 7}$ \\
\hline & $\mathbf{3 0}$ & $\mathbf{1 0 0}$ \\
\hline
\end{tabular}

Sumber: Mustika Ratu 


\section{Market Sreening technique}

Berdasarkan daftar pertanyaan1 sampai dengan 10 yang di berikan kepada responden maka, dapat disimpulkan hal hal sebagai berikut :

Jumlah score $=1246$

Score ideal adalah $=10 \times 5 \times 30=1500$

Score $=$

\begin{tabular}{|l|l|l|l|l|l|l|l|l|l|}
\hline 131 & 128 & 123 & 133 & 137 & 116 & 116 & 139 & 112 & 111 \\
\hline
\end{tabular}

Jadi posisi Mustika ratu pada Market screening technique adalah $=(1246 / 1500)$ X $100 \%=83 \%$ yang berarti PT. Mustika Ratu sudah menjalankan market screening technique yang kriterianya ditentukan oleh pengalaman calon distributor, Jumlah outlet yang ditangani, kunjungan kenegara tujuan ekspor sebelum penentuan distributor, Market size dari suatu Negara, Jumlah populasi, Income per kapita, Peraturan Negara setempat, skala prioritas pengembangan Negara tujuan ekspor, dan pelaksanaan pameran.

\section{Hambatan Pemasaran}

Pertanyaan 11 sampai dengan 20 menganalisa mengenai hambatan pemasaran dan hasil perhitungan dari kuesioner adalah sebagai berikut:

Score Ideal $=1500$

Score $=961$ atau $64.1 \%$

\begin{tabular}{|l|l|l|l|l|l|l|l|l|l|}
\hline 71 & 110 & 100 & 73 & 88 & 90 & 129 & 112 & 95 & 93 \\
\hline
\end{tabular}

PT. Mustika Ratu pada saat ini masih dapat mengatasi hambatan pemasaran akan tetapi pada level yang minimum (64.1\%), dimana elemen terendah ada pada kesulitan pendaftaran produk di Negara setempat (57 poin) dan pendistribusian produk belum mencapai semua outlet yang tersedia (59 poin).

\section{Kualitas Produk Yang dipasarkan}

Analisa kualitas produk PT. Mustika Ratu dalam Pemasaran Internasional di Saudi Arabia, dapat dijelaskan dari pertanyaan 21 sampai dengan 30, dengan hasil analisa adalah sebagai berikut :

Score ideal $=1,500$

Score $=1031$ atau $68.7 \%$

\begin{tabular}{|l|l|l|l|l|l|l|l|l|l|}
\hline 131 & 81 & 81 & 90 & 111 & 111 & 105 & 112 & 96 & 113 \\
\hline
\end{tabular}


Kualitas produk PT. Mustika Ratu secara umum, masih diatas rata - rata, sehingga dapat bersaing pada pasar Internasionala pada umumnya, hanya pada pertanyaan no. 22 diterangkan bahwa penjualan PT. Mustika Ratu di saudi Arabia tidak meningkat dalam lima tahun terakhir dikarenakan kurangnya inovasi produk yang sesuai dengan karakteristik masyarakat Saudi Arabia, aktifitas promosi yang terbatas serta pada pertanyaan no 23, disimpulkan bahwa produk Mustika Ratu tidak mudah untuk ditemukan di outlet, atau masih terjadi masalah pada distribusi produk.

\section{Kesulitan dalam pelaksanaan strategi pemasaran Internasional khususnya promosi.}

Kesulitan pelaksanaan strategi pemasaran di Saudi Arabia dapat dianalisa melalui pertanyaan 31 sampai dengan 40, dengan hasil analisa sebagai berikut:

Score Ideal $=1,500$

Score $=946$ atau $63.1 \%$

\begin{tabular}{|l|l|l|l|l|l|l|l|l|l|}
\hline 84 & 79 & 104 & 95 & 89 & 122 & 83 & 104 & 82 & 104 \\
\hline
\end{tabular}

Melihat score yang ada maka dapat disimpulkan bahwa masih terdapat hambatan dalam pelaksanaan promosi, dan khususnya pertanyaan no: 31, 37 dan 39, dimana pemasangan iklan jarang dilakukan, pemilihan model wanita yang sesuai dengan karakter produk tidak dapat dilakukan karena hambatan budaya, serta kegiatan public relations jarang dilaksanakan.

\section{a. Promotion Strategy}

- Penempatan medical representative

- Pembuatan Website

○ Iklan Majalah terkemuka :

- Alyum Newspaper for Eastern Province: SAR 473,200/year - 250,000 copies

- Alyum Newspaper for Western Province: SAR 548,912/year - 500,000 copies

- Okaz Daily Neswpaper: SAR 360,000/year - 220,000 copies

- Al Seha Health Magazine (Monthly): SAR 84,000/year

- Al Watan Newspaper: SAR 10,909/year

- $\quad$ Al Haya Newspaper: SAR 5,600/year

- Al Ozra Magazine: SAR 9,000/year

\section{b. Placement (Distribusi)}

Strategi distribusi yang dilakukan oleh PT. Mustika Ratu adalah dengan menunjuk Eksklusif Distributor untuk Saudi Arabia dan timur tengah . 
Pada saat ini saluran distribusi diarahkan melalui apotik, pasar modern (super market) dan direct marketing.

Tabel IV-4. Outlets (Apotik)

\begin{tabular}{|c|l|c|c|l|}
\hline NO & \multicolumn{1}{|c|}{ NAME OF OUT LETS } & $\begin{array}{l}\text { NUMBER OF } \\
\text { BRANCHES }\end{array}$ & $\begin{array}{l}\text { CREDIT } \\
\text { DAYS }\end{array}$ & \multicolumn{1}{|c|}{ REGION } \\
\hline 1 & Al Nahdi Pharmacy Group & 364 & 60 & Throught Kingdom \\
\hline 2 & Al Atlas Pharmacy Group & 103 & 60 & Throught Kingdom \\
\hline 3 & Abdul Khader Al Saggaf Pharmacy & 40 & 90 & Riyadh \\
\hline 4 & M.Hussain Al Saggaf Pharmacies & 50 & 90 & Riyadh \\
\hline 5 & Al Farabi Pharmacies & 10 & 45 & Riyadh \\
\hline 6 & Bait Al Seha Pharmacies & 20 & 21 & Riyadh \\
\hline 7 & Kunooz Al Seha Pharmacies & 26 & 30 & Riyadh \\
\hline 8 & Zahrat Al Rowdah Pharmacies & 26 & 45 & Riyadh \\
\hline 9 & Al Dawa Pharmacies & 110 & 30 & Eastern Province \\
\hline 10 & Al Haya Pharmacies & 45 & 30 & Eastern Province \\
\hline 11 & Al Khonaini Pharmacies & 40 & 120 & Eastern Province \\
\hline 12 & Al Muttahida Pharmacies & 142 & 45 & Western Province \\
\hline 13 & Al Nahas Pharmacies & 24 & 60 & Western Province \\
\hline 14 & Al Asia Pharmacies & 18 & 90 & Western Province \\
\hline 15 & Al Mustakbal Pharmacies & 12 & 60 & Western Province \\
\hline 16 & AL Madeena Pharmacies & 5 & 30 & Northen Province \\
\hline 17 & Al Surehi Pharmacies & 5 & 30 & Northen Province \\
\hline 18 & Al Mabaseen Pharmacies & 3 & 60 & Northen Province \\
\hline 19 & Al Salman Pharmacies & 12 & 90 & Northen Province \\
\hline 20 & Al Future Pharmacies & & & \\
\hline
\end{tabular}

Analisa SWOT

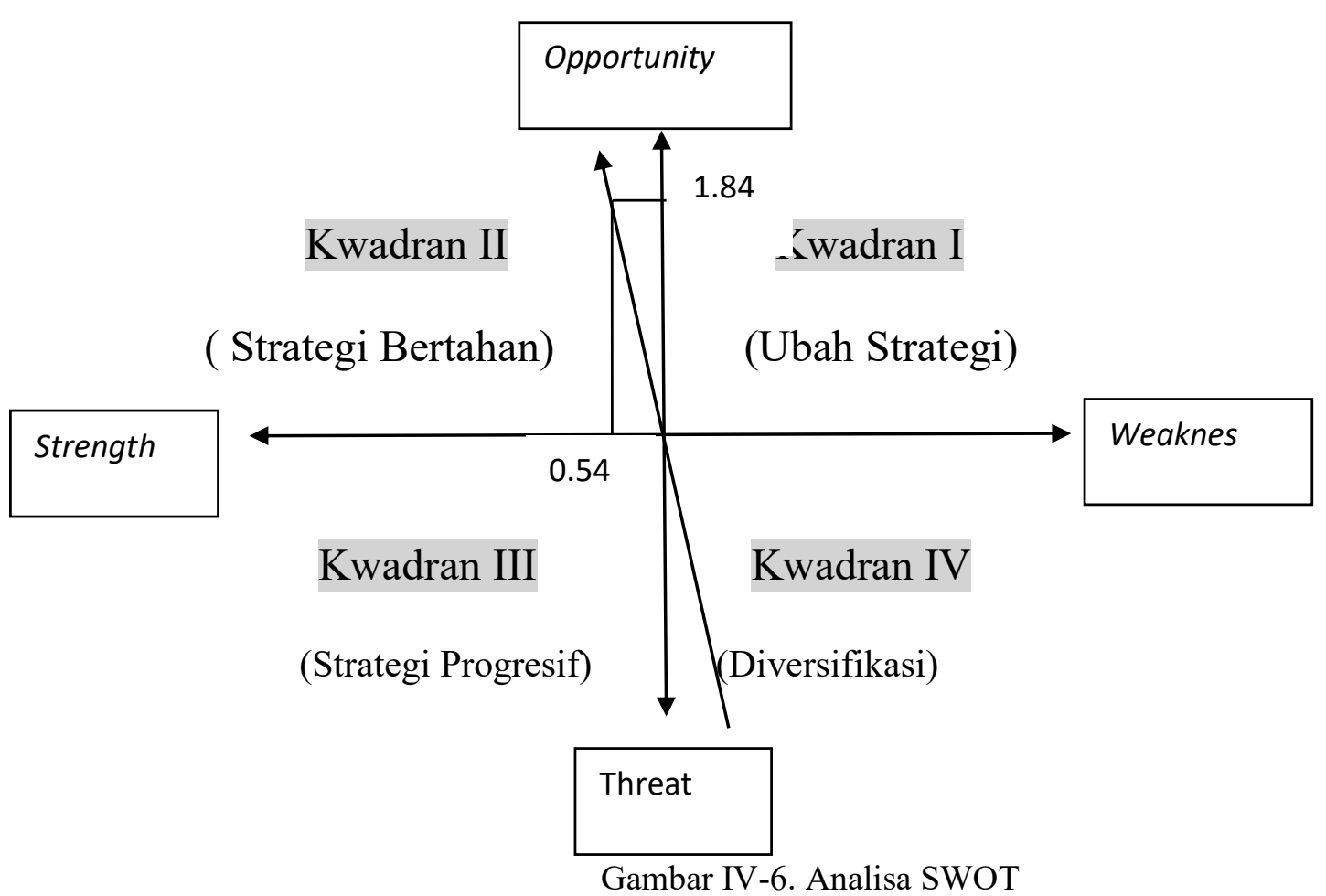


Tabel IV-7. Tabel Analisa Swot

\begin{tabular}{|r|l|r|r|r|}
\hline NO & STRENGTH & SCORE & BOBOT & TOTAL \\
\hline 21 & PRODUK DIKENAL & 4.4 & 0.044423 & 0.195461 \\
\hline 24 & KEMASAN MENARIK & 3 & 0.035249 & 0.105746 \\
\hline 27 & KEMASAN TERSEGEL & 3.5 & 0.040077 & 0.14027 \\
\hline 28 & PUNYA NO. REGISTRASI & 3.7 & 0.042492 & 0.157219 \\
\hline 29 & ADA UJI KLINIS & 3.2 & 0.036697 & 0.117431 \\
\hline 30 & GUDANG MENGIKUTI ISO & 3.8 & 0.043457 & 0.165138 \\
\hline 31 & SERING BERIKLAN & 2.8 & 0.032834 & 0.091936 \\
\hline 32 & BUDGET PROMOSI & 2.6 & 0.030903 & 0.080348 \\
\hline 33 & AKTIFITAS PROMOSI & 3.5 & 0.041043 & 0.14365 \\
\hline 34 & MUDAH DITEMUKAN & 3.2 & 0.038146 & 0.122067 \\
\hline 36 & PEMILIHAN MEDIA & 4.1 & 0.047803 & 0.195992 \\
\hline 10 & RISET PASAR & 3.7 & 0.043457 & 0.160792 \\
\hline 25 & KELUHAN RENDAH & 3.7 & 0.043457 & 0.160792 \\
\hline 3 & PENUNJUKAN DISTRIBUTOR & 4.1 & 0.047803 & 0.195992 \\
\hline & TOTAL 14 & & & $\mathbf{2 . 0 3 2 8 3}$ \\
\hline
\end{tabular}

\begin{tabular}{|c|c|c|c|c|}
\hline NO & WEAKNESS & SCORE & BOBOT & TOTAL \\
\hline 12 & LAMA PENDAFTARAN PRODUK & 3.7 & 0.042492 & 0.157219 \\
\hline 16 & BAHASA & 3 & 0.0338 & 0.1014 \\
\hline 17 & $\begin{array}{l}\text { BIAYA PENDAFTARAN PRODUK } \\
\text { MAHAL }\end{array}$ & 4.3 & 0.049252 & 0.211782 \\
\hline 18 & BIYA LISTING & 3.7 & 0.04394 & 0.162578 \\
\hline 19 & SISTEM KONSINYASI & 3.2 & 0.03718 & 0.118976 \\
\hline 20 & BIAYA PENGIRIMAN & 3.1 & 0.035249 & 0.109271 \\
\hline 26 & RASA PRODUK & 3.7 & 0.04394 & 0.162578 \\
\hline 15 & LOKASI OUTLET JAUH & 2.9 & 0.034766 & 0.100821 \\
\hline 38 & $\begin{array}{l}\text { SALES PROMOTION JARANG } \\
\text { DILAKUKAN }\end{array}$ & 3.5 & 0.041043 & 0.14365 \\
\hline 39 & $\begin{array}{l}\text { PUBLIC RELATION JARANG } \\
\text { DILAKUKAN }\end{array}$ & 2.7 & 0.030903 & 0.083438 \\
\hline 40 & $\begin{array}{l}\text { EVALUASI PROMOSI JARANG } \\
\text { DILAKUKAN }\end{array}$ & 3.5 & 0.039594 & 0.13858 \\
\hline & TOTAL 11 & & 1 & 1.490295 \\
\hline
\end{tabular}




\begin{tabular}{|r|l|r|r|r|}
\hline NO & OPPORTUNITY & SCORE & BOBOT & TOTAL \\
\hline 1 & PENGALAMAN DISTRIBUTOR & 4.4 & 0.080911 & 0.356009 \\
\hline 2 & JUMLAH OUTLET & 4.3 & 0.080126 & 0.34454 \\
\hline 4 & MARKET SIZE & 4.4 & 0.083268 & 0.366379 \\
\hline 5 & POPULASI & 4.6 & 0.085625 & 0.393873 \\
\hline 6 & INCOME PER KAPITA & 3.9 & 0.073841 & 0.287981 \\
\hline 8 & AREA PLANNING & 4.6 & 0.087196 & 0.4011 \\
\hline 9 & PAMERAN & 3.7 & 0.068342 & 0.252867 \\
\hline 22 & PENJUALAN MENINGKAT & 2.7 & 0.049489 & 0.133621 \\
\hline 14 & TIPE OUTLET & 2.4 & 0.046347 & 0.111233 \\
\hline 23 & HARGA SUDAH SESUAI & 2.7 & 0.05106 & 0.137863 \\
\hline & TOTAL 10 & & & 2.785467 \\
\hline
\end{tabular}

\begin{tabular}{|r|l|r|r|r|}
\hline NO & THREAT & SCORE & BOBOT & TOTAL \\
\hline 34 & KUALITAS MERUPAKAN & & & \\
\hline 35 & TUNTUTAN & 3.2 & 0.062058 & 0.198586 \\
\hline 7 & PERATURAN NEGARA SETEMPAT & 3 & 0.053417 & 0.160251 \\
\hline 16 & PENDIRIAN PERUSAHAAN & 3 & 0.073056 & 0.284918 \\
\hline 37 & MODEL WANITA TIDAK & 3 & 0.054988 & 0.164965 \\
\hline & DIPERBOLEHKAN & 2.8 & 0.050275 & 0.14077 \\
\hline & TOTAL 5 & & & \\
\hline
\end{tabular}

Berdasarkan hasil analisa SWOT maka dapat disimpulkan sebagai berikut:

Sumbu X $=$ Strength - Weakness $=2.03-1.49=0.54$

Sumbu $Y=$ Opportunity - Threat $=2.79-0.95=1.84$

Posisi produk Mustika ratu di pasar saudi arabia, mempunyai kekuatan(Strength) yang tidak besar akan tetapi kesempatan (opportunity) yang ada cukup besar untuk meningkatkan penjualan, strategi yang harus digunakan adalah strategi progresif atau suatu strategi operasional untuk memperkuat posisi dipasar.

\section{Analisa BCG Matriks}

Berdasarkan Brand pada Mustika ratu dengan posisi sebagai berikut :

\begin{tabular}{|c|c|}
\hline $\begin{array}{lll}\text { Arus kas sedang }+/ \text { atau - } & \text { STAR }\left(^{*}\right) \\
\text { : - BASK } & 10 \% \\
& \text {-TSRH SPA 3\% }\end{array}$ & $\begin{array}{l}\text { Arus kas sangat negatif } \\
\text { Question Mark : } \\
\quad-\quad \text { Kenanga }\end{array}$ \\
\hline
\end{tabular}




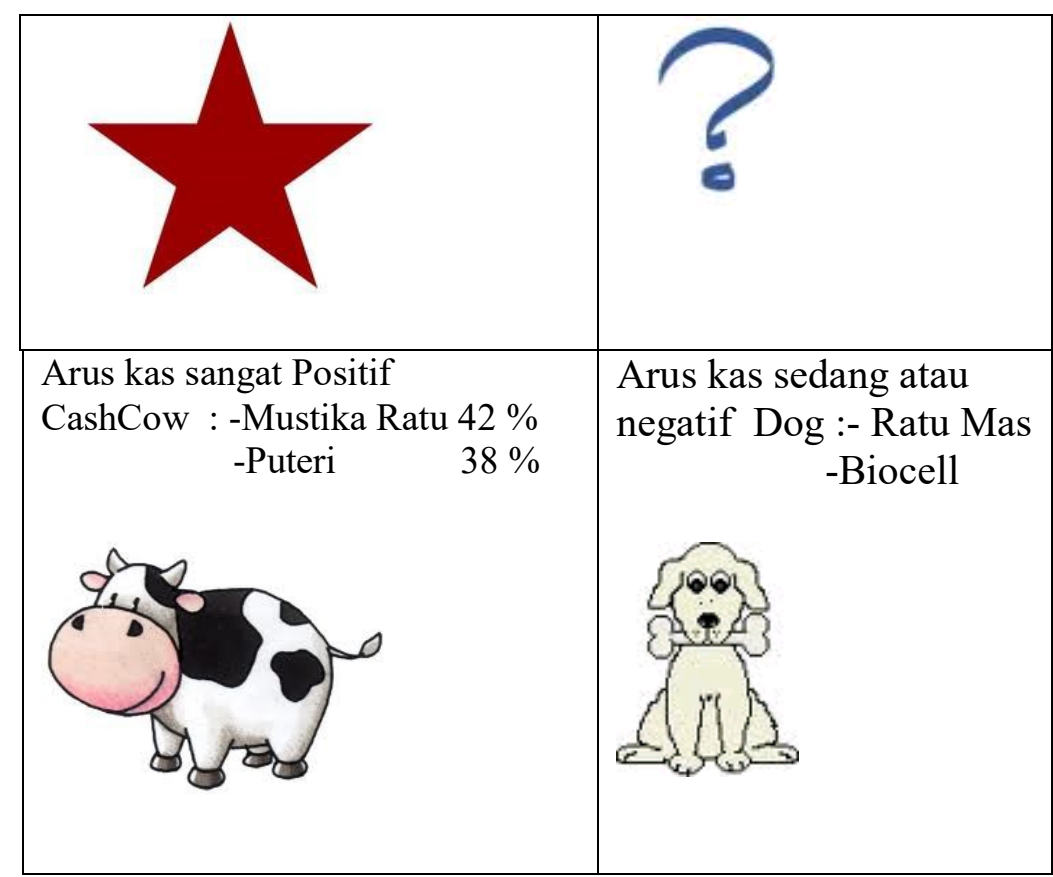

Gambar IV-7. BCG Matriks

Berdasarkan Share yang ada, maka analisa Matriks BCG pada PT. Mustika Ratu tbk.,dapat disimpulkan sebagai berikut :

\section{i. Sapi Perah (Cash Cow)}

Produk Mustika Ratu dan Puteri merupakan sapi perah atau pun tulang punggung dari mayoritas penjualan Mustika Ratu. Demikian juga dengan produk Mustika ratu yang dijual di Saudi Arabia, bermula dari sekitar 300 produk yang ada di pasar Saudi Arabia dari ber macam macam merk produk Mustika ratu hingga akhirnya menjadi hanya empat produk yaitu Jamu tea, Tonic Tea, Ginteh dan Jamu tea rasa madu yang semuanya dibawah merk Mustika ratu.

ii. Bintang(Star)

Pada posisi Bintang Merk Bask dan Taman Sari Royal Heritage SPA mulai menunjukan pertumbuhan, Bask mempunyai pertumbuhan $10 \%$ dan diprediksi akan meningkat mengingat line kosmetik untuk Pria ini mempunyai kelebihan dari segi kemasan dibanding pesaing lainnya seperti Mandom, Gillett walaupun dari segi penjualan saat ini masih dibawah. Sedangkan SPA produk mempunyai pangsa pasar sendiri yaitu kelas atas, tetapi persaingan di kelas ini sangatlah padat, sehingga setelah lebih dari sepuluh tahun perkembangannya tidak cepat.

iii. Tanda tanya (Question Mark) 
kenanga adalah produk yang mempunyai pangsa pasar rendah, kenanga adalah merk yang ditujukan kepada market segmen bawah, dan persaingan di bawah sangat banyak sebagai contoh Viva, ada lagi merk dari cina yang masuk kepasaran. Sehingga secara perlahan Brand tersebut akan tersingkir, mengingat cash flow yang negatif.

iv. Anjing ( dog)

Pada posisi ini, merek Ratu Mas, Biocell, Biocolor, ditujukan kepada konsumen dengan sosial status

A( kelas atas) dan akan bersaing dengan produk luar seperti Revlon,SK-II, L'Oreal,L'Occitane,Body shop,sehingga sulit untuk dapat bersaing dan akan memerlukan biaya marketing yang tinggi.

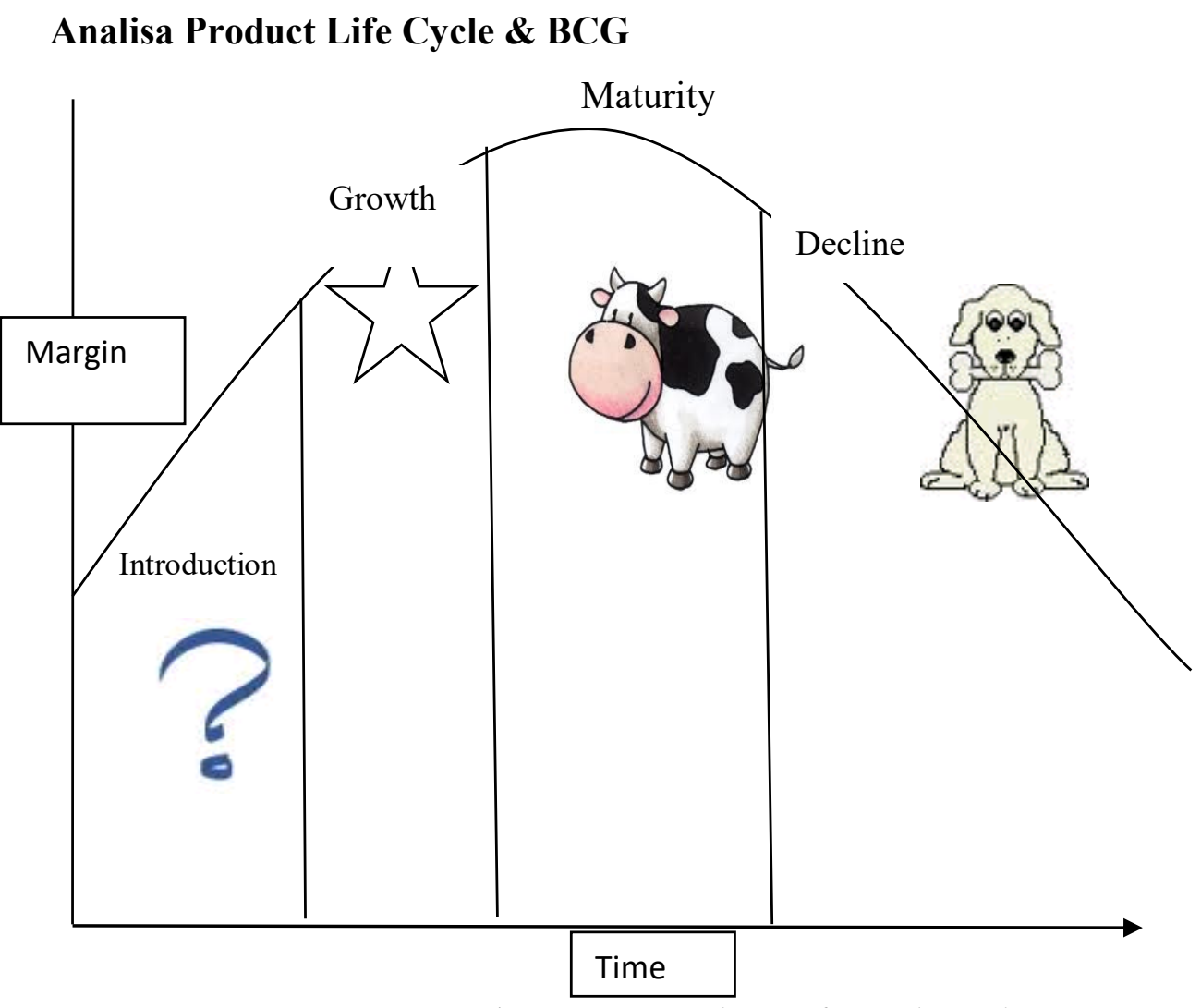

Secara umum melihat akan pertumbuhan bisnis PT. Mustika Ratu dapat disimpulkan bahwa PT. Mustika Ratu berada pada posisi Maturity dengan pertumbuhan berfluktuasi antara posisi puncak pertumbuhan $7.2 \%$ di tahun 2008 hingga $6.6 \%$ di tahun 2010, Rasio 
lancar dapat diartikan bahwa PT. Mustika Ratu sangat konservatif dalam menjaga likuiditasnya.

\section{Analisa Keuangan}

IKHTISAR POKOK KEUANGAN KONSOLIDASI

consolidated Financial Highlights

\begin{tabular}{|c|c|c|c|c|c|}
\hline $\begin{array}{l}\text { Dalam Jutaan Ruplah } \\
\text { In munuon Ruplah }\end{array}$ & 2015 & 2014 & 2013 & 2012 & 2011 \\
\hline $\begin{array}{l}\text { Penjualan Bersih } \\
\text { Net Sales }\end{array}$ & 428.093 & 434.747 & 358,127 & 458.197 & 406,316 \\
\hline $\begin{array}{l}\text { Laba Kotor } \\
\text { Gross prorit }\end{array}$ & 246,546 & 246,996 & 200,442 & 257,108 & 227,510 \\
\hline $\begin{array}{l}\text { Laba Usaha } \\
\text { Incame (Lass) fram Operation }\end{array}$ & 5,239 & 11,625 & $(10,128)$ & 41.592 & 41,513 \\
\hline $\begin{array}{l}\text { Laba Bersih } \\
\text { Net /ncome }\end{array}$ & 1,046 & 7,054 & $(6.700)$ & 30.751 & 27,868 \\
\hline $\begin{array}{l}\text { Jumlah Saham Beredar } \\
\text { Total Share/ssued }\end{array}$ & 428 & 428 & 428 & 428 & 428 \\
\hline $\begin{array}{l}\text { Laba (Rugi) Usaha per Saham } \\
\text { Incame from Operation per Share }\end{array}$ & 12 & 27 & -24 & 97 & 97 \\
\hline $\begin{array}{l}\text { Laba (Rugi) Bersih per Saham } \\
\text { Net incame per Share }\end{array}$ & 2 & 16 & -16 & 72 & 65 \\
\hline $\begin{array}{l}\text { Modal Kerja Bersih } \\
\text { Net Working Capital }\end{array}$ & 278,090 & 272,427 & 261,854 & 294,234 & 274.411 \\
\hline $\begin{array}{l}\text { Aset Lancar } \\
\text { Current Assets }\end{array}$ & 380.988 & 376.694 & 313.664 & 352,880 & 326,474 \\
\hline $\begin{array}{l}\text { Jumlah A set } \\
\text { Total Assets }\end{array}$ & 497,090 & 500.138 & 439.584 & 455.473 & 422,493 \\
\hline $\begin{array}{l}\text { Liabilitas Jangka Pendek } \\
\text { Corrent Liabilities }\end{array}$ & 102,898 & 104,267 & 51.810 & 58,646 & 52.063 \\
\hline $\begin{array}{l}\text { Jumlah Liabilitas } \\
\text { Total Labilities }\end{array}$ & 120,064 & 121,183 & 61,792 & 69.586 & 64,064 \\
\hline $\begin{array}{l}\text { Ekuit as } \\
\text { Stookholders Equity }\end{array}$ & 377.026 & 378.955 & 377,791 & 385,887 & 358,428 \\
\hline
\end{tabular}

\begin{tabular}{|c|c|c|c|c|c|}
\hline $\begin{array}{l}\text { Rasio } \\
\text { (Ratios) }\end{array}$ & 2015 & 2014 & 2013 & 2012 & 2011 \\
\hline $\begin{array}{l}\text { Laba Kotor / Penjualan Bersih } \\
\text { Grass Pr afit to Net Sales }\end{array}$ & $57.6 \%$ & $56.8 \%$ & $56.0 \%$ & $56.1 \%$ & $56.0 \%$ \\
\hline $\begin{array}{l}\text { Laba ( Rugi) / Penjualan Bersih } \\
\text { Income ( Loss) from Operation to } \\
\text { Net Sales }\end{array}$ & $1.2 \%$ & $2.7 \%$ & $-2.8 \%$ & $9.1 \%$ & $10.2 \%$ \\
\hline $\begin{array}{l}\text { Laba ( Rugi) / Penjualan Bersih } \\
\text { Return on Sales }\end{array}$ & $0.2 \%$ & $1.6 \%$ & $-1.9 \%$ & $6.7 \%$ & $6.9 \%$ \\
\hline $\begin{array}{l}\text { Laba ( Rugi) / Total Aset } \\
\text { Return on Assets }\end{array}$ & $0.2 \%$ & $1.4 \%$ & $-1.5 \%$ & $6.8 \%$ & $6.6 \%$ \\
\hline $\begin{array}{l}\text { Laba ( Rugi) / Ekuit as } \\
\text { Return on Equity }\end{array}$ & $0.3 \%$ & $1.9 \%$ & $-1.8 \%$ & $8.0 \%$ & $7.8 \%$ \\
\hline $\begin{array}{l}\text { Ekuit as / Jumlah A set } \\
\text { Equity to Assets }\end{array}$ & $75.8 \%$ & $75.8 \%$ & $85.9 \%$ & $84.7 \%$ & $84.8 \%$ \\
\hline $\begin{array}{l}\text { Aset Lancar / Kewajiban Lancar } \\
\text { Current Ratio }\end{array}$ & $370.3 \%$ & $361.3 \%$ & $605.4 \%$ & $601.7 \%$ & $627.1 \%$ \\
\hline $\begin{array}{l}\text { Kewajiban / Ekuitas } \\
\text { Debt to Equity }\end{array}$ & $31.8 \%$ & $32.0 \%$ & $16.4 \%$ & $18.0 \%$ & $17.9 \%$ \\
\hline $\begin{array}{l}\text { Kewajiban / Jumlah A ktiva } \\
\text { Debt to A ssets }\end{array}$ & $24.2 \%$ & $24.2 \%$ & $14.1 \%$ & $15.3 \%$ & $15.2 \%$ \\
\hline
\end{tabular}

Sumber :http://www.mustika-ratu.co.id/annualreport/anrep2015.pdf

Rasio profitabilitas :

Margin laba bersih : laba bersih : penjualan $=0.23 \%$

Rasio pertumbuhan :

Penjualan : $-1.2 \%$ (menurun dibanding thn 2014)

Laba bersih/penjualan bersih : $1.2 \%$ thn. 2015 (menurun $56 \%$ dibanding tahun 2014)

Rasio Likuiditas

Rasio Lancar : asset lancar / kewajiban lancar $=370,3 \%$ 
Melihat rasio yang ada maka dapat disimpulkan bahwa PT. Mustika Ratu tbk., adalah perusahaan yang sehat dimana kemampuan likuiditasnya sangat baik, demikian juga kalau dilihat dari debt asset ratio yang menunjukan posisi hutang terhadap asset perusahaan hanya $24.6 \%$ adalah tidak berpengaruh,tetapi harus diwaspadai dengan teliti tren menurun dalam segi laba dan debt rasio, penjualan harus ditingkatkan karena rasio profitabilitasnya (laba: Penjualan bersih) hanya 1,2 \%di tahun 2015 hal ini tidak menarik bagi seorang investor untuk membeli sahamnya dan jauh dibawah pertumbuhan ekonomi nasional.

\section{Pelaksanaan Strategi Pemasaran Internasional}

i. PT. Mustika Ratu melakukan strategi pemasaran di saudi Arabia dengan melakukan penetapan positioning yang "Less for more" yang mengacu pada kepuasan konsumen yang mendapatkan manfaat produk untuk menjadi slim, tidak ada akibat samping (side effect) dengan harga yang sedikit lebih murah, yang juga bisa digambarkan melalui bauran pemasaran. Dimana dari segi produk termasuk premium, harga premium low, penggunaan promosi dengan mengutamakan prestige dan mimpi menjadi langsing, sedangkan distribusi dengan menggunakan Intensif distribusi ke jalur apotik, super market untuk kalangan menengah atas, sedangkan toko toko kecil bukan merupakan target, karena pencitraan yang mereka tekankan.

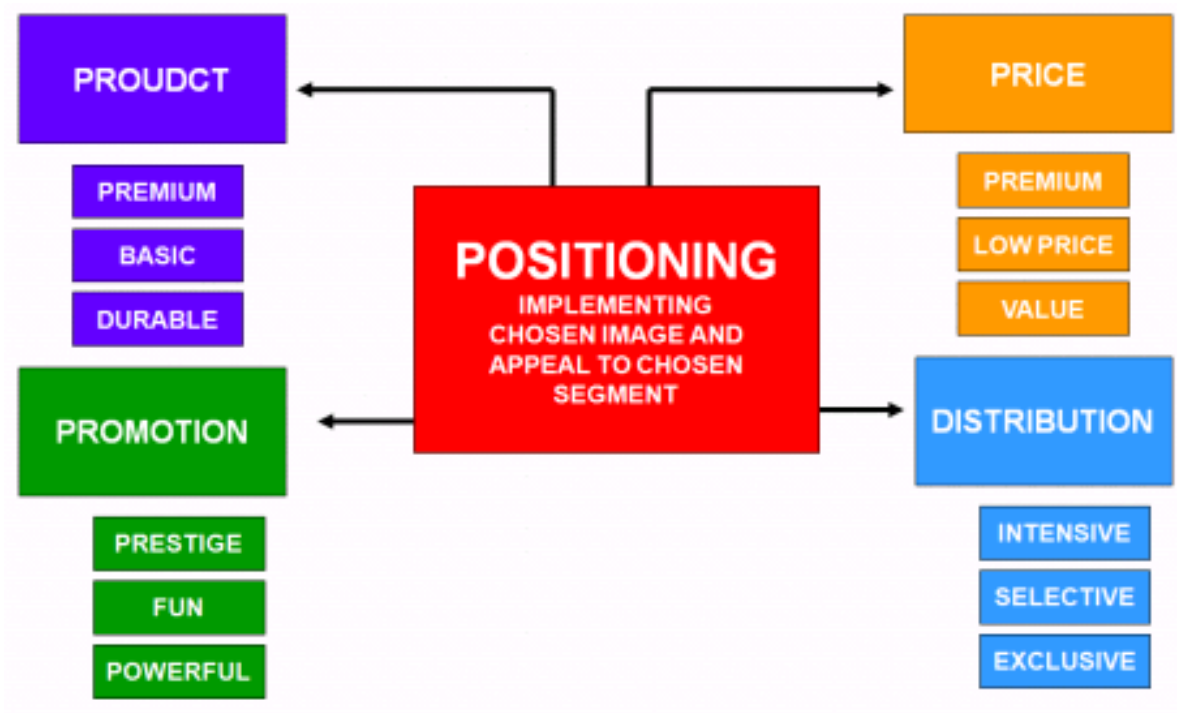

Gambar IV-9. Gambar product Positioning strategy

Sumber : http://www.consumerpsychologist.com/ 


\section{ii. Strategi harga}

Harga yang digunakan dalam transaksi dengan Saudi Arabia adalah FOB Jakarta dan menggunakan U\$ dollar.

Cost yang dikeluarkan oleh distributor untuk pengadaan barang adalah :

Produk $($ U\$2.5 $) \quad=$ SAR 9.375

Transportasi $\quad=$ SAR 0.21

Import tax $4 \% \quad=$ SAR 0.38

Total $=$ SAR 9.965 adalah cost (landed Price)

dimana didalam industry kosmetik biasanya COGM (Cost of goods manufactutured) berkisar antara $30 \%$ - $40 \%$, sehingga harga yang sesuai adalah SAR 33 .

\section{iii. $\quad$ Strategi Promosi}

Pada dasarnya Mustika Ratu memberikan 10\% dari pembelian berupa marketing support, yang digunakan oleh pihak distributor dalam melakukan aktifitas promosinya, biasanya karakter iklan dapat berupa Prestige, fun, powerful, akan tetapi tetap tidak bisa menggunakan model wanita yang dihubungkan dengan kecantikan. Untuk meningkatkan penjualan di Saudi Arabia, maka diperlukan sebuah strategi promosi yang terpadu.

\section{iv. Strategi distribusi}

Distribusi barang spenuhnya dilakukan oleh PT. Mustika Ratu menurut order yang diterima dari pihak distributor, mayoritas menggunakan pengiriman melalui laut.Sedangkan distributor menggunakan Intensive distribution strategy, walaupun belum dapat meng cover semua outlet yang ada.

\section{PEMBAHASAN}

Berdasarkan data pertanyaan yang di berikan kepada responden maka dapat disimpulkan sebagai berikut :

1. PT. Mustika Ratu telah menjalankan Market Screening Technique dengan mendapatkan score $83 \%$ yang kriteria ditentukan oleh pengalaman distributor, market size, jumlah outlet yang ditangani, jumlah populasi dan income perkapita.

2. Hambatan pemasaran dari segi legal, network dan finance dapat di analisa dari pertanyaan 11 sampai dengan 20 , dan dari hasil perhitungan kuesioner didapatkan score $64.1 \%$, yang 
berarti masih terdapat hambatan pemasaran seperti peraturan yang ketat terkait registrasi produk di Arab Saudi yang memakan waktu lebih kurang satu tahun,biaya registrasi mahal, biaya pengiriman barang yang cukup mahal,network yang terkendala oleh budaya setempat. Sistem konsinyasi yang mencapai tiga sampai empat bulan merupakan kendala dari segi finance.

3. Kualitas produk mempunyai score $68.7 \%$ hal ini mencerminkan bahwa produk Jamu Tea cukup dikenal, penjualan berada pada posisi yang sama selama tujuh tahun belakangan ,sedangkan dari segi promosi hanya mendapatkan score $63.1 \%$ karena terkendala oleh budget promosi $10 \%$, Jarang melakukan pemasangan iklan, model wanita diberi aturan yang ketat, kegiatan public relations jarang dilakukan.

\section{KESIMPULAN DAN SARAN}

\section{A. KESIMPULAN}

Berdasarkan hasil analisa terhadap strategi pemasaran Internasional PT. Mustika Ratu, maka dapat disimpulkan :

1. Market Screening Technique merupakan strategi yang sudah dilaksanakan oleh PT. Mustika Ratu, dengan skor 83\% yang disimpulkan dari pertanyaan 1 sampai dengan 10 , dengan menggunakan skala likert, meliputi kriteria: pengalaman calon distributor, jumlah outlet yang ditangani, market size, jumlah populasi dan income per kapita.

2. Hambatan pemasaran yang terjadi di Saudi Arabia diambil dari kuesioner adalah 64.16\%, meliputi pendaftaran produk pada Ministry of Health Saudi Arabia yang berkisar satu tahun, biaya listing yang mahal, faktor budaya berpengaruh kuat, serta berdasarkan SWOT analisis terlihat bahwa posisi PT. Mustika Ratu sebenarnya dapat berada pada posisi STAR dan dapat menggunakan strategi bertahan akan tetapi karena menganut system konservatif maka pada saat ini berada pada posisi maturity dan pada $B C G$ Matrix berada pada cash cow pada kwadran III, sehingga terlihat pertumbuhan yang stabil ,sedangkan kalau dilihat dari analisa keuangan dengan rasio profitabilitas $1.2 \%$ tahun $2015,2.7 \%$ tahun 2014 dan $-2.8 \%$ tahun 2013 berada pada posisi cash cow kwadran III stabil dengan catatan perlu perhatian khusus, untuk mengatasi hambatan pemasaran yang ada maka Global Market Entry Strategy yang dilaksanakan oleh PT. Mustika Ratu saat ini melalui ekspor, harus dirubah menjadi bentuk 
subsidiary company yang bertugas untuk melaksanakan program pemasaran $4 \mathrm{P}$ serta mengembangkan segmentation, target dan positioning bagi produk produk Mustika Ratu yang lain, dan hal ini akan menjamin permintaan akan produk tertentu dapat dipenuhi oleh Mustika Ratu dengan segera, promosi terpadu dapat dilaksanakan dengan kontrol yang baik, harga retail dapat ditetapkan dengan tepat, sedangkan dari distribusi dapat dilaksanakan intensif distribusi strategi yang dapat menjangkau outlet lebih luas sehingga dapat memaksimalkan jumlah outlet yang tersedia.

3. Didalam pelaksanaan strategi pemasaran Internasional faktor - faktor internal eksternal dianalisa dengan menggunakan SWOT analisis terlihat bahwa sumbu X atau (Strength - Weakness) mempunyai nilai 0.55 dan sumbu Y (Opportunity - Threat) mempunyai nilai 1.85 sehingga faktor strength perlu diperkuat seperti beriklan, kemasan diperbaharui agar lebih menarik, produk tersegel rapi akan mengakibatkan kualitas produk terjamin sehingga menimbulkan kepercayaan konsumen , budget promosi dinaikan dari $10 \%$ menjadi $20 \%$, riset pasar dilakukan dan terus menekan keluhan pelanggan, sedangkan faktor weaknes harus dapat dikurangi : sales promotion , public relation harus dilaksanakan secara terencana, lama pendaftaran produk, biaya pendaftaran produk dan biaya listing harus lebih efisien, serta perilaku konsumen(consumer behavior) seperti cara beriklan, buyer decision process dapat diantisipasi. Dengan menekan elemen weaknes, berarti penguatan pada elemen strength akan terjadi dan Mustika Ratu akan bisa berada pada posisi STAR pada BCG matriks atau GROWTH pada product life cycle.

\section{B. Saran}

Berdasarkan kesimpulan diatas, maka dapat diberikan saran- saran sebagai berikut :

1. Market Screening Technique terus dilakukan dan berdasarkan hasil kuesioner dengan menggunakan skala likert, hasilnya cukup baik $(82.8 \%)$, riset pasar, pameran, harus mempunyai program dan penunjukan distributor perlu adanya evaluasi yang terukur setiap tahun.

2. Dalam menghadapi hambatan pemasaran, PT. Mustika Ratu diharapkan untuk dapat terus menghilangkan elemen weakness seperti : biaya pendaftaran yang tinggi dan lama , biaya listing produk, melakukan sales promotion dan public relation yang terencana melakukan strategi progresif yaitu dengan terus mengembangkan Unique Product Proposition (USP) dengan Inovasi produk yang sesuai dengan pasar menggunakan Blue 
Ocean Strategy yaitu dengan menghapuskan faktor - faktor yang telah diterima oleh industri seperti hapuskan penggunaan bahan kimia, kurangi kemasan yang tidak ramah lingkungan, dapat terurai bahkan menjadi pupuk bagi tumbuhan sesuai dengan konsep societal marketing, ciptakan faktor - faktor yang belum pernah ditawarkan seperti jamu yang mempunyai rasa yang disukai bukan pahit, dan terakhir tingkatkan promosi, dan apabila hal ini diterapkan, maka akan tercipta kurva nilai baru dari produk, dan kompetisi menjadi tidak relevan, dan diharapkan Mustika Ratu akan berada pada posisi GROWTH

3. Didalam pengembangkan strategi pemasaran internasional,kualitas produk yang masuk dalam unsur strength seperti : ada uji klinis pada pertanyaan 29, punya nomor registrasi, tersegel,selanjutnya harus sering disosialisasikan dengan beriklan dan dibantu dengan program promosi yang terpadu serta evaluasi semua kegiatan secara rutin, serta penambahan biaya promosi , maka diharapkan penjualan meningkat $20 \%$ dengan perhitungan bahwa pada saat ini jumlah outlet yang di cover berjumlah 1.148 dengan penjualan per bulan mencapai 17.500 box , maka setiap outlet hanya berhasil menjual 15 box per bulan dengan menambah marketing support menjadi berkisar 20\% atau sekitar 900,000,000 Rupiah, maka consumer Promotion dan Trade Promotion dapat dilakukan, dengan sasaran loyal customers, competitor's customers, brand switchers dan price buyers, menggunakan kupon, diskon, sampling, bundle produk, sehingga peningkatan aktifitas promosi, diharapkan menambah penjualan menjadi 20 box perbulan per outlet, akan meningkatkan penjualan minimum 20 persen sampai $33 \%$. Setiap program promosi harus ditetapkan sasarannya, kemudian dilakukan evaluasi untuk perbaikan, berupa Model Strategi Pemasaran Internasional.

Dengan Input produk yang mempunyai keunggulan kompetitif dan terus mempertajam market screening technique serta memperkuat faktor internal (strength) dan menekan weakness, juga ditunjang oleh faktor eksternal (opportunity) yang besar, maka output yang dihasilkan berupa strategi pemasaran internasional yang baik, dengan outcome berupa peningkatan penjualan di Saudi Arabia, apabila masih terjadi cognitive dissonance pada Konsumer maka perlu dilakukan evaluasi.

\section{DAFTAR PUSTAKA}

1. Amir M.S,2003, Strategi Memasuki Pasar Ekspor, Penerbit PPM, Jakarta 
2. Bennet, R., dan Blythe, J., 2002, International Marketing,Third Edition, Bell \& Bain Ltd, Glasgow

3. Cateora, P., 2007, International Marketing, Mc Graw hill - irwin, New York

4. Hiam,A., 1992, The Portable MBA, John Wiley\&sons,Inc., Massachusetts

5. http://apps.who.int/medicinedocs/en/d/Jwhozip57e/4.3.2.

6. http://www.consumerpsychologist.com/

7. http://www.euromonitor.com/slimming-products-in-saudi-arabia/report

8. http://www.ft.com/intl/cms/s/0/ba5a8c12-9350-11df-bb9a00144feab49a.html\#axzz1USrS2z2w

9. https://www.cia.gov/library/publications/the-world-factbook/geos/sa.html

10. Kotabe, M. dan Helsen, K., 1998, Global Marketing Management, John Wiley \& son, USA

11. Kotler, P., 2003, Principle of Marketing, Pearson education, Australia

12. Kotler, P., 1989, Manajemen Pemasaran jilid 1, Edisi 5, Penerbit Erlangga, Jakarta

13. Murray, C., The Marketing Gurus, Penguin group(USA), 2006

14. Pearce II, J., dan Robinson Jr, R.,2008, Manajemen Strategis, Edisi 10, Penerbit Salemba, Jakarta

15. Sugiyono, 2010, Metode Penelitian Kuantitatif Dan Kualitatif R\&D, Penerbit ALFABETA, Bandung

16. Rangkuti, F., 2009, Riset pemasaran, cetakan ke IX, PT Gramedia Pustaka Utama, Jakarta.

17. Soegoto, E., 2009, Entreprenuership Menjadi Pebisnis Ulung, PT Elex Media Komputindo, Jakarta.

18. Stanton,W,1991, Prinsip Pemasaran,ed.7, Penerbit Erlangga, Jakarta.

19. Voerman, L.,1972, The Export Performance Of European SMEs, Labyrint Publication, Holland. 